\title{
Collaborative innovation in the family SME: conceptualization, goals, and success factors
}

\author{
Unai Arzubiaga $^{\mathrm{a}^{*}}$, Amaia Maseda $^{\mathrm{a}}$, Amaia Uribarri ${ }^{\mathrm{a}}$, Jesús Manuel Palma-Ruiz ${ }^{\mathrm{b}}$

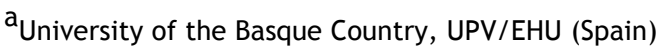 \\ buniversidad Autónoma de Chihuahua (Mexico)
}

Received 28 September 2018; accepted 19 December 2019

\section{JEL}

CLASSIFICATION

M19, 031, 032

\section{KEYWORDS}

Collaborative

innovation, Family

SME; Innovative

capabilities;

Innovative

attitudes;

Management team

CÓDIGOS JEL

M19, 031, 032

\section{PALABRAS CLAVE}

Innovación

colaborativa; PYME

familiar;

capacidades

innovadoras;

actitudes

innovadoras; equipo

directivo

\begin{abstract}
In a constantly changing environment, collaborative innovation enables the knowledge creation and new product designs, the improved efficiency of the production process, and the reduction of time-to-market. However, the achievement of such results in the family SME depends mainly on the unique characteristics of this type of organization, which in turn, represent the most widespread kind of business worldwide. Therefore, the objective of this article is to analyze how the composition of the management team, the factors related to the capabilities -cognitive factors, absorptive capacity, and innovative trajectory- and the attitudes -preservation of SEW and intraorganizational behavior- of the decision makers, mainly influenced by the family, affect when designing and implementing collaborative innovation processes in a successful way.
\end{abstract}

\begin{abstract}
La innovación colaborativa en la pyme familiar: conceptualización, objetivos y factores de éxito

Resumen En un entorno en constante cambio, la innovación colaborativa permite la creación de conocimiento y de nuevos diseños, la mejora de la eficiencia del proceso de producción y la reducción de tiempo para la comercialización de los nuevos productos. Sin embargo, la consecución de tales resultados en las pymes familiares depende en buena medida de las características propias de este tipo de organizaciones, que a su vez representan el tipo de empresa más extendida a nivel mundial. Por lo tanto, el objetivo de este artículo es analizar como la composición del equipo directivo, los factores relacionados con la capacidad -factores cognitivos, capacidad absorptiva y trayectoria innovadora- y las actitudes - preservación del legado socio-emocional y comportamiento intra-organizacional- de los decisores, en buena medida influenciados por la familia, afectan al momento de diseñar e implementar los procesos de innovación colaborativa de manera exitosa.
\end{abstract}

http://dx.doi.org/10.24310/ejfbejfb.v9i2.5265

Copyright 2019: Unai Arzubiaga, Amaia Maseda, Amaia Uribarri Jesús Manuel Palma-Ruiz.

European Journal of Family Business is an open access journal published in Malaga by UMA Editorial. ISSN 2444-8788 ISSN-e 2444-877X This work is licensed under a Creative Commons Atribution-NonCommercial-ShareAlike 4.0 International License (CC BY-NC-SA 4.0).

This study is based on the Master's Thesis titled "Innovation in the Basque family business" of the Master's Degree in Business Management from an Innovation and Internationalization Perspective of the University of the Basque Country (UPV/EHU), developed by the student Amaia Uribarri and supervised by the directors Amaia Maseda and Unai Arzubiaga. 


\section{Introduction}

In today's dynamic and global environment, in which the demands of the different agents that intervene in the market change at a dizzying speed and the development of new technologies is continuous, companies are forced to adapt to new scenarios to offer innovative answers (Paunov, 2012). It is in this context that one can easily understand the reason why studies on innovation processes have boomed in recent years (Holt and Daspit, 2016; Kraiczy, Hack, and Kellermans, 2014). Far from being conceived as a linear, delimited and automatic process, innovation is considered as a changing process, with no apparent limits and, above all, dynamic (Chang, Hughes, and Hotho, 2011). This process allows the experience and knowledge of different people and organizations to interact, that is to say, that the know-how flows between the various agents, favoring its feedback (Jensen, Johnson, Lorenz, and Lundvall, 2007). Thus, the mechanisms that allow interaction within the organizations themselves (collaboration between different units, or the participation of the company's personnel in the innovation processes) and the networks with which the company relates to its environment (other companies, universities, research, and technology centers) are gaining increasing prominence (Öberg, 2016). In this context, De Massis, Frattini, and Lichtenthaler (2012) argued that given the interaction between agents has a significant impact on the future of innovation, and collaborative innovation will have a very prominent role soon, both internally (intraorganizational collaboration) and externally (inter-organizational collaboration).

Collaborative innovation is defined as voluntary agreements among independent firms, who exchange and share capital, information, knowledge, and technology to achieve a common innovation goal (Feranita, Kotlar, and De Massis, 2017; Un, Cuervo-Cazurra, and Asakawa, 2010). It is a particularly interesting strategic option for small and medium-sized enterprises (SMEs) since it enables the development of new resources and capabilities to maintain and improve their competitiveness in the market (Muñoz-Bullón, Sanchez-Bueno, and De Massis, 2019). Besides, it allows to have resources that could not be obtained otherwise, or that would imply an excessive cost, and all this without having to give up the desire to be creative and innovative (Miles, Miles, and Snow, 2005). However, this activity is not without risks, given the complexity of the process and the numerous agents and factors that intervene. This complexity is accentuated by the nature of family-owned SMEs, which represent between $80-90 \%$ of commercial companies and are responsible for $70 \%$ of the employment generated in the private sector (Instituto de Empresa Familiar de España, 2016). In this regard, the lack of studies on collaborative innovation in the field of family businesses is particularly striking (Casprini et al., 2017; De Massis, Frattini, and Lichtenthaler, 2012; Feranita et al. 2017). Thus, the research carried out on the collaborative innovation process has focused mainly on the study of large companies (Spithoven, Vanhaverbeke, and Roijakkers, 2013), leaving the smaller ones relegated to a second stage, even though these smaller companies, as previously stated, represent the critical element of economic and social development.

For all the above reasons, this article focuses on the collaborative innovation processes in the family SME. For this purpose, a conceptualization of this phenomenon is presented by analyzing the factors that affect the success of the family SME when dealing with collaborative innovation processes, as well as the perceived benefits. In this way, this article makes at least two theoretical contributions. Firstly, a contribution to the innovation literature is formed by carrying out a conceptualization of the collaborative innovation process, aiming to deepen in its solid foundation to delve into and inspire a more rigorous approach. Secondly, a comprehensive approach of collaborative innovation processes in the context of the family business is offered, by identifying their distinctive characteristics and how such can influence this type of strategy.

From a practical point of view, this study also contributes to those responsible for designing and executing public policies in the field of innovation. It is expected for public institutions to act as facilitators of business innovation processes (Kontinen and Ojala, 2011), with the difficult task of distributing the limited public resources among companies that want to pursue innovative activities (Zúñiga-Vicente, AlonsoBorrego, Forcadell, and Galán, 2014). In this regard, two of the main distinctive features of family businesses are their long-term orientation and their close ties with the communities where they are based (Lumpkin, Brigham, and Moss, 2010), the fact of highlighting the benefits that family SMEs attain from innovation processes enables public institutions to assess the effect of the invested public resources more precisely. The remainder of this article is structured as follows. Next section describes a conceptualization of collaborative innovation, highlighting which are the objectives sought through the implementation of this type of processes. Subsequently, the main distinctive characteristics of family SMEs are briefly discussed. Afterward, the different elements that make up the theoretical model of 
collaborative innovation processes in family SMEs are thoroughly explained, focusing on the composition of the management team as well as on the differential factors related to capacity and attitude of family SMEs. In the last section, the contributions of this study are summarized, and a series of relevant aspects are outlined for future studies.

\section{Collaborative Innovation}

\section{Conceptualization}

Collaborative innovation is defined as the creation of innovations beyond the limits of the company, and even the industry or sector, through the exchange of ideas, knowledge, experiences, and opportunities (Ketchen, Ireland, and Snow, 2007). It refers to a process of creation and development that involves multiple actors, from outside and from within organizations, working together in order to generate ideas, concepts or solutions in the form of product, process or service (Skippari, Laukkanen, and Salo, 2017) for business or for their own use (Haefliger, 2012). During its development and regularly, the collaborating agents reveal the results of their individual and collective efforts with the agreed partners (Baldwin and von Hippel, 2011).

Social capital is defined by Bourdieu (1986: 248) as "the sum of real or potential resources linked to the possession of a lasting network of relations of knowledge and mutual recognition." It is considered a key element for strategic collaborations, increasing the probability of successful collaborations due to the trust and willingness to share resources among the partners (Hitt, Ireland, Camp, and Sexton, 2001; Nahapiet and Ghoshal, 1998; Siebert, Kraimer, and Liden, 2001). In this sense, Galán and Castro (2004: 108) pointed out that "confidence can lead to joint efforts and, for this reason, it is considered as an antecedent and an extraordinary lubricant of collaboration." Also, they added that "when two units begin to trust one another the willingness to share resources increases without worrying about the advantages that the other party will incur."

In this way, the existence of inter-organizational trust implies excellent coordination of tasks among the companies that sustain relationships or transactions, providing relevant knowledge about their norms, routines, and procedures (Gulati, Nohria, and Zaheer, 2000). In this regard, Davis and Eisenhardt (2011) emphasized the significant interactions among the several members of the supply chain, which is one of the main productive ecosystems where collaborative innovation occurs, through the search for complementary partners with the resources needed (Venkatesh and Yadav, 2011).

\section{Objectives of collaborative innovation}

Companies committed to collaborative innovation pursue several specific goals that can be grouped in three major groups: enabling knowledge creation and new product designs, improved efficiency of the production processes, ad reduction of time-to-market (Skippari et al., 2017).

\section{Enabling knowledge creation and new product designs}

Collaboration among different organizations or agents in the innovation chain, from the idea generation to its conversion into a product or service, stimulates the cross-fertilization of shared knowledge and experiences (Swink, 2006), which leads to a higher number of initiatives on new products or services (Faems, van Looy, and Debackere, 2005). These benefits can be especially valuable in the case of technological innovations by facilitating staff involved in R\&D activities with greater access to information and experiences (Roy and Sivakumar, 2010). For example, the collaboration between different organizations increases the quality of product design solutions, thus increasing their attractiveness to customers (Skippari et al., 2017).

Collaborative innovation can also be exciting when companies interact with either potential or current customers (Haefliger, 2012). On this regard, one of the most novel phenomenon developed in recent years is the co-design of products, which is the result of the collaborative work between companies and consumers (Fuchs and Schreier, 2011). This collaboration allows consumers to benefit from improvements in the products they usually consume, ensuring that these products will have better acceptance in the market, thus reducing the likelihood of rejection by better understanding what customers value (Tsai, 2009). In this search and identification of new markets, it is also worth noting that customized products and services tailored to niche audiences, which are willing to pay more if they can design the product themselves (Franke, Schreier, and Kaiser, 2010).

Improved efficiency of the production process Collaborative innovation can also be beneficial concerning efficiency and cost reduction in the development and production stages (Min et al., 2005). Thus, the collaboration between different companies allows managing learning and knowledge of the product creation processes (Öberg, 2016). A partnership facilitates cost reduction and enables the maximization and shared use of product platforms, global product 
designs, and generations of such products, among others (Swink, 2006).

A clear example of this practice is that carried out by the Spanish family supermarket chain Mercadona with its suppliers (Negocios en Navarra, 2016). Thus, Mercadona establishes collaborative ties with its inter-suppliers both in processes (reducing electricity and water consumption, minimizing waste, and optimizing logistics) and products. Mercadona, aware of its customers' needs and tastes, transfers them to its suppliers specialized in manufacturing, with whom it maintains stable and long-term commercial relationships. Thus, this joint consideration provides richer insights on network innovation output, producing in 2015 alone more than 100 new process improvements and at the same time, establishing solid foundations to collaborate in product and process development shortly.

\section{Reduction of time-to-market}

Collaborative innovation can also result in a reduction in the time needed to commercialize a new product, a factor that allows companies to extend their market participation (Davis and Eisenhardt, 2011). Multi-organizational innovation teams tend to find solutions more quickly since they have a full range of knowledge sources (Ganesan et al., 2009), which allows faster and more numerous iterations of designs (Holmen, Aune, and Pedersen, 2013). On the other hand, collaboration encourages the reuse and better use of previous design and development work (Street and Cameron, 2007). Besides, the partnership allows the development process to begin without the need to fully complete the last phase design since the most relevant information is accessible to those responsible for making decisions during the product development phase (Swink, 2006).

Finally, although collaborative innovation, in general, leads to the development of new products and services (Rumball, 2007), how the process is developed and even the results acquired vary depending on the type of company that carries it out (Filip, Hansen, and Frölunde, 2016). SMEs have fewer resources than necessary to carry out basic research (Roxas, Piroli, and Sorrentino, 2011). Thus, collaborative innovation processes of SMEs often include as collaborating agents to universities, vocational training institutes and communities, groups and business clusters arising around some of the aspects to be developed as well as to different companies involved in the innovation process (Von Hippel and Von Krogh, 2003).

\section{The Family SME and its unique characteristics}

A family business is identified as such by the participation of the family in the company. The family influence is determined regarding ownership, management, and government (Steiger, Duller, and Hiebl, 2015; Mazzi, 2011). In addition to family involvement, the behavior and desire to be a family business is undoubtedly another distinguishing feature of this type of organization (Dawson and Mussolino, 2014; Chrisman, Chua, and Sharma, 2005). In this sense, one of the most recognized definitions of family business is the one proposed by Chua, Chrisman, and Sharma (1999), as that entity where the government and management falls on a dominant coalition controlled by members of the same family or a small number of families, whose desire is the sustainable maintenance of the business for future family generations.

The actions of family businesses are based on the dynamic interaction between family and business subsystems with a transgenerational expectation; that is, a desire to keep the company under the family control throughout different generations (Anderson and Reeb, 2003; Habbershon, Nordqvist, and Zellweger, 2010), differentiating from nonfamily counterparts (Zellweger, Eddleston, and Kellermanns, 2010). Thus, family businesses tend to exhibit a clear long-term orientation in their strategic decisions (Le Breton-Miller and Miller, 2006). In this sense, Goel and Jones (2016) pointed out that the need to balance and align the interests of the family and the company means that family businesses have resources and unique governance that directly affects their strategic decision-making. The desire to maintain control of the company in the long-term can translate into a more conservative behavior to avoid risk exposure (Gómez-Mejía, Haynes, Núñez-Nickel, Jacobson, and Moyano-Fuentes, 2007). This fact is known in the literature as the desire to maintain the socio-emotional wealth (SEW), which is one of the priority objectives of family businesses. SEW refers to a set of intangible elements such as the feeling of belonging, the perpetuation of family values, the preservation of the family dynasty, or family altruism, among others (Gómez-Mejía et al., 2007).

The distinctive cultural elements of the family business, long-term orientation, and risk aversion as a result of their desire to preserve the socioemotional wealth have a positive effect on strategic decision-making, and therefore, on the adoption of innovation strategies (Arzubiaga, 2019). These strategies are driven by the management team, who are usually influenced by the opinion of the family, given that family members are usually included in the top management team or the board of directors (Minichilli, Corbetta, and MacMillan, 2010). The

Arzubiaga, U., Maseda, A., Uribarri, A., Palma Ruiz, J.M. (2019). Collaborative innovation in the family SME: conceptualization, goals, and success factors. European Journal of Family Business, 9(2), 12-114. 
fact that the management team is composed of family and non-family members of different generations and that there might be managers who are also owners means that both businessand family objectives have to be considered simultaneously (Kraiczy et al., 2014; Zellweger, 2007).

\section{Determining factors in collaborative innovation in the Family SME}

The collaborative innovation process has a series of unique characteristics when it takes shape in the family SME. In line with the above, the factors related to the capabilities and attitude of these companies affect their collaborative innovation processes. Likewise, these factors are also influenced by the characteristics of the management teams, in which the familial element can have a significant influence (Rondi, De Massis, and Kotlar, in press), farther in the case of SMEs given the limited number of personnel in the top management (Figure 1).

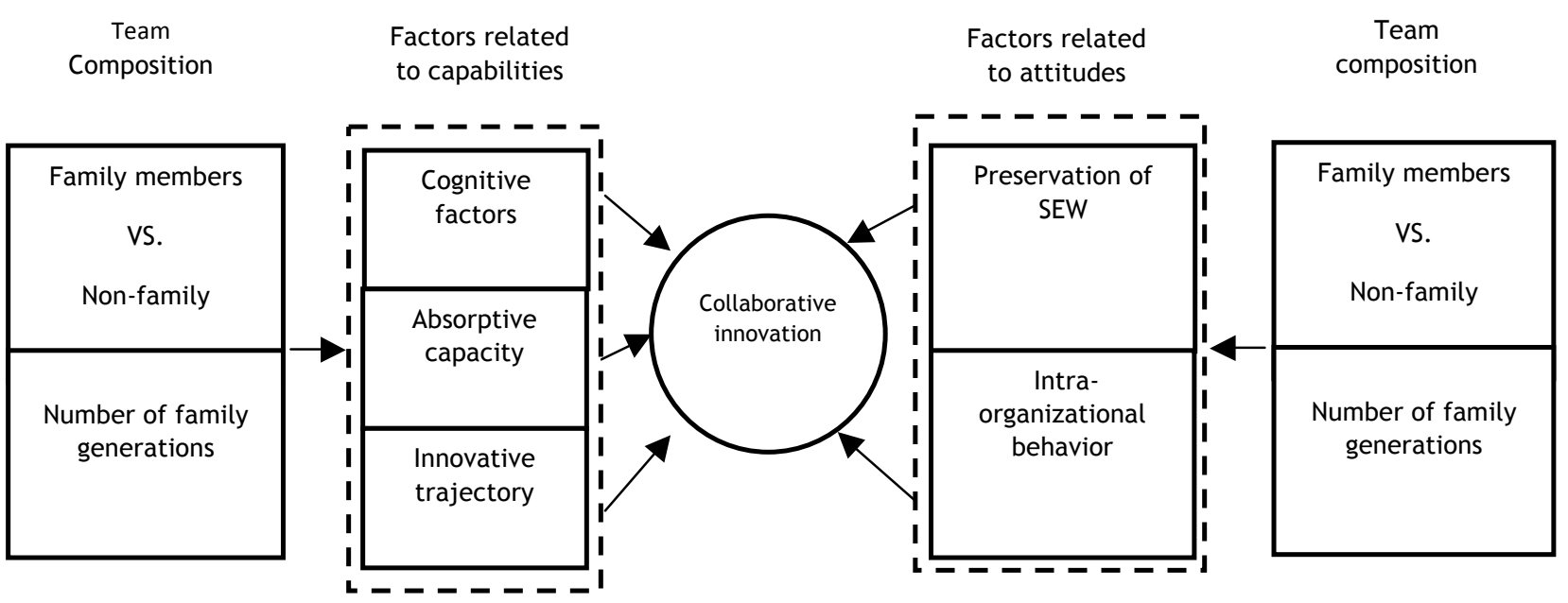

Figure 1 Factors related to the success of collaborative innovation in the family SME.

Based on the scheme presented in Figure 1, the following sections elucidate on each of the elements that contribute to and affect the collaborative innovation process of the family SME.

\section{The management team composition}

The top management team composition and its diversity are aspects with a strong influence on the behavior and decision-making of the organization (Ling and Kellermanns, 2010). In addition to the diverse elements common to any company, family SMEs have two diversity factors, which are considered unique and differentiated (Kraiczy et al., 2014): the ratio of family members in the management team and the number of generations involved in the management team (Arzubiaga, Maseda, and Iturralde, 2017).

Concerning the presence of family members in top management, their influence as a group stems from an educational base and common organizational culture, sharing experience, and knowledge acquired over time (Lozano-Posso and Urbano, 2017; Minichilli et al., 2010). Besides, they have unique values such as commitment, long-term orientation, and customer service, which gives them a more robust organizational culture and values (Chrisman, Chua, Pearson, and Barnett, 2012). However, a high percentage of family members in the management team can also minimize the broad-mindedness and knowledge of other organizations (Kraiczy et al., 2014), a pivotal point to achieve high efficiency in innovation processes. In this sense, the presence of non-family managers usually provides more diverse external knowledge and perspectives (Talke, Salomo, and Rost, 2010), due to their different managerial skills acquired outside the family business (Veider and Matzler, 2015) and better network contacts with external advisors. These advisors can provide experiences and technical knowledge in various areas (Classen, Van Gils, Bammens, and Carree, 2012), which can be vital to establishing relationships 
with third parties to design and implement collaborative innovation projects.

The number of family members can also affect the attitude of managers when making decisions about innovation in general (Minichilli et al., 2010), and collaborative innovation in particular (Magistretti, Dell'Era, De Massis, and Frattini, 2019). Thus, non-family managers may need to demonstrate that their employment is justified (Hiebl, 2015), so they will seek to increase their managerial impact and leave their professional imprint through the design and implementation of more risky projects (Casillas, Moreno, and Barbero, 2011). Also, this fact accentuates the difference in family members concerning the attitude toward risk, minimizing the risk of investment in innovation, with the ultimate goal of preserving the socioemotional wealth of the family in the organization (Gómez-Mejía et al., 2010).

Regarding the number of family generations involved in the top management team, such inter-generational presence is considered a vital diversity factor when making decisions about the innovation processes (Kellermanns and Eddleston, 2006). Thus, the involvement of different generations in the management team allows to diversify the knowledge as a result of the various educational backgrounds, experiences (Talke et al., 2010), different perspectives, and even, different network contacts (Chirico, Sirmon, Sciascia, and Mazzola, 2011). In this way, it is easier to identify the needs of new clients and markets, and the innovation processes can be more efficient by combining the new knowledge provided by the new generations with the tacit knowledge contributed by previous generations (Litz and Kleysen, 2001). However, knowledge combinations across different generations also require a flexible attitude that allows integrating this knowledge (De Clercq and Belausteguigoitia, 2015), shelving inter-generational tensions as to how to address the innovation in collaboration with third parties.

In short, the two primary sources of diversity in the management team composition play a prominent role in the factors related to the capabilities and attitudes of family SMEs when designing and implementing collaborative innovation processes.

\section{Factors related to capabilities}

The competence of the decision-making bodies in the strategic area is also of particular importance when launching innovation projects (Talke et al., 2010). Thus, in the field of collaborative innovation, cognitive factors stand out (Skippari et al., 2017), the absorption capacity (Filip et al., 2016) and the innovative trajectory (Hibbert and Huxham, 2010) as critical factors to success in collaborative innovation processes.

\section{Cognitive factors}

The cognitive factors of the agents involved in collaborative innovation processes play a crucial role in the design and development of innovations (Corsaro, Cantú, and Tunisini, 2012) and depend, to a large extent, on the knowledge acquired, the experiences lived and the unique social interactions experienced by individuals or teams (Marcel, Barr, and Duhaime, 2010).

As noted above, in family SMEs, most of the times, family members are responsible for leading and making decisions about aspects related to innovation (Sciascia, Mazzola, and Chirico, 2013). Usually, those family members share similar elements such as academic background, business know-how, and business culture acquired over the years (Lozano-Posso and Urbano, 2017; Minichilli et al., 2010). Such excessive homogeneity of cognitive factors, derived from a high proportion of family members in positions of responsibility for innovation processes, can result in a lack of knowledge diversity and diverse perspectives (Chrisman, Fang, Kotlar, and De Massis, 2015). Thus, generating a mental rigidity in the cognitive maps of these decision-makers (König, Kammerlander, and Enders, 2013). It is generally acknowledged that non-family members are the ones contributing more knowledge and new perspectives (Arzubiaga, Iturralde, Maseda, and Kotlar, 2018; Talke et al., 2010), different management capabilities, and better access to external network contacts (Veider and Matzler, 2015). This knowledge diversity and skills promotes the use of external information, thus reinforcing the absorption capacity of the company (Classen et al., 2012).

Nonetheless, the concurrence of new family generations in the decision areas can help alleviate the excessive mental rigidity in the cognitive maps of the management teams with a large proportion of family members of the same generation (Cruz and Nordqvist, 2012). Younger generations will contribute new ideas and network contacts to successfully design collaborative innovation projects (Litz and Kleysen, 2001). For example, the implementation of new technologies and tools (Fang, Kotlar, Memili, Chrisman, and De Massis, 2018), which represents essential knowledge to meet the challenges of a dynamic market (Sciascia et al., 2013). In this sense, family SMEs with high heterogeneous teams into innovation will have a greater tendency towards collaborative innovation and a higher probability of success. 


\section{Absorptive capacity}

The absorption capacity refers to the ability of the organization to assess, assimilate, and apply new knowledge from collaborators (Cohen and Levinthal, 1990). It is based on a series of routines and organizational processes through which companies acquire, assimilate, transform, and exploit new knowledge (Zahra and George, 2002). Therefore, absorption capacity plays a vital role when collaborating with different agents in collaborative innovation processes (Reagans, Zuckerman, and McEvily, 2004).

In the family SME, the absorption capacity varies according to the capabilities of the people who lead the innovation processes (Kotlar, De Massis, Frattini, and Kammerlander, 2019; Kraiczy et al., 2014). Thus, SMEs with a more significant proportion of non-family members in the company, represents a diversity factor regarding knowledge, skills, and expertise (Veider and Matzler, 2015), with a higher probability of success in collaborative innovation processes. In this sense, mixed teams have a higher potential absorption capacity that allows them to be more receptive to the acquisition of external knowledge and more effective when assimilating that know-how (Alexiev, Jansen, Van den Bosch, and Volberda, 2010). In the same way, a more significant proportion of non-family members also increases the real absorption capacity of family SMEs, that is, to transform and recombine the information and knowledge acquired from different sources for later exploitation (Rodan and Galunic, 2004).

Given that family SMEs are reluctant to incorporate managers from outside the family, the absorption capacity can be driven by the inclusion of new generations in the decisionmaking processes on innovation projects and collaborative innovation (Kellermanns, Eddleston, Barnett, and Pearson, 2008). Thus, the teams responsible for designing and implementing collaborative innovation projects that enjoy a higher absorption capacity will be more effective as they have a higher ability to exploit the rents resultant from this collaboration.

\section{Innovative trajectory: depth and breadth}

The know-how and expertise accumulated during the organizational life cycle are also influential factors when it comes to success in collaborative innovation processes (Filip et al., 2016). Thus, a long history of innovation leads to a wide range of recombinations of knowledge and experience, which will be of greater importance to the extent that the innovative trajectory has been more profound, in terms of accumulation of knowledge in a specific area, and more broadly, in terms of knowledge diversity in several areas (Davis and Eisenhardt, 2011).
Family SMEs with a more substantial proportion of family members tends to have deeper innovative trajectories, acquiring tacit knowledge about a specific area over the years in the company. This gives them an advantage of knowing how to discriminate, within this scope, which collaborative innovation projects will be more likely to succeed, and identify from the first moment those that should be abandoned (Katila and Ahuja, 2002). However, the lack of knowledge diversity, expertise, and network contacts of those teams composed mostly by family members lessen the innovation trajectory (Arzubiaga, Kotlar, De Massis, Maseda, and Iturralde, 2018), which results in less knowledge and experience about the recombinations of novel elements (Ahuja and Katila, 2004) and translates into less effective collaborative innovation processes.

Consequently, balanced teams concerning family and non-family members, in principle, seem to be in a more advantageous situation to address diverse collaborative innovation projects. Relatedly, the presence of new generations in those bodies responsible for collaborative innovation projects can help to alleviate, in a certain way, the limited breadth of ideas and knowledge that senior management teams of family firms usually portray (Sciascia et al., 2013).

\section{Factors related to attitudes}

The second axis on which the collaborative innovation processes of family SMEs pivot deals with the attitudes of the teams responsible for designing and implementing those processes, as shown in Figure 1. In this regard, two different characteristics can be distinguished that affect the collaborative innovation processes, such as the preservation of socio-emotional wealth (SEW) and risk aversion (Gómez-Mejía et al., 2007), as well as intra-organizational behavior (Nordqvist, Sharma, and Chirico, 2014).

\section{Preservation of SEW}

The influence of the familial factor on family businesses has been related both to economic results, including competitive advantage and wealth creation, and to results unrelated to the financial scope, including the preservation of tradition, the strengthening of family ties, and the value creation across generations (Pearson, Carr, and Shaw, 2008). Consequently, decisionmaking also has this twofold facet, pursuing economic objectives, as well as those objectives closely linked to the family (Mahto et al., 2010; Souder, Zaheer, Sapienza, and Ranucci, 2016), such as the preservation of the socio-emotional wealth (Gomez-Mejía et al., 2007).

In this sense, family businesses tend to estimate at all times how different strategic decisions can 
affect the business family (Chua, Chrisman, and De Massis, 2015; Vieira, 2014), prioritizing those processes and initiatives that avoid, as far as possible, the assumption of risks for the future of the business family (Gomez-Mejía, Makri, and Kintana, 2010; Kotlar, De Massis, Wright, and Frattini, 2018). Given that collaborative innovation brings uncertainties typical of this type of operations, family SMEs may not be willing to assume certain risks. On the one hand, innovation processes are inherent to chance, since they do not offer certainty of the results (Veider and Matzler, 2015). This uncertainty about the investment recovery, both in financial terms and intangible resources, can jeopardize innovation initiatives in general (Brinkerink and Bammens, 2018; Naldi, Nordqvist, Sjöberg, and Wiklund, 2007). On the other hand, family SMEs are often very reluctant to share knowledge with other collaborators outside the organization (Ireland and Webb, 2007). These companies, many of them located in the industrial sector, have developed for years know-how based on learning-by-doing (Chirico, 2008), resulting in tacit knowledge about a series of specialized products (Duran, Kammerlander, Van Essen, and Zellweger, 2016).

In general, SMEs usually have limited access to resources and lack of specific knowledge and technical expertise within a particular area (George, 2005), leading to difficulties when entering collaborative innovation due to their reluctance to lose experience and not seize knowledge opportunities from the collaborators. Thus, faced with the challenge of disclosing their know-how in addition to not being able to take advantage of what has been contributed by the other participants in the innovation processes, the participation of family SMEs in collaborative innovation with third parties is constrained (Debicki, Kellermanns, Chrisman, Pearson, and Spencer, 2016). Putting at risk the competitive advantage that implies having the differential know-how, in exchange for not obtaining clear benefits.

Given that these issues may affect the future viability of the organization, family SMEs will be conservative when taking part in collaborative innovation processes (De Massis, Chirico, Kotlar, and Naldi, 2013). This conservative attitude will be more accentuated in the case of family SMEs with a large proportion of family members amongst those who make strategic decisions (Kraiczy et al., 2014). This conservative attitude of family members can be weakened with more diversified management teams (Zahra, 2005). Thus, the heterogeneity due to the inclusion of non-family members and the concurrence of different family generations will help to create a prone attitude towards collaboration with third parties in innovation projects.

\section{Intra-organizational behavior}

Innovation is fundamentally a collaborative effort between people who share ideas, perspectives, and values (Adler and Kwon, 2002). That is why social capital, understood as the set of values, norms, and attitudes that foster collaborative dynamics is a resource that favors the exchange of knowledge and information (Nahapiet and Ghoshal, 1998), as well as innovation processes (Sánchez-Famoso, Iturralde, and Maseda, 2015). The family business, given its peculiar characteristics linked to the family with solid business values and strong social ties (Hall, Melin, and Nordqvist, 2001), are companies with essential reserves of social capital in which interand intra-organizational relations have a strong influence on their behavior and dynamics (Sánchez-Famoso, Maseda, and Iturralde, 2017). In family SMEs, family members in charge of innovation decision-making tend to consider internal ideas and perspectives of higher value than those coming from outside the organization (Menon and Pffefer, 2003). Even though, there may be certain misgivings by family members to the recognition of the ideas and advice of the non-family group inside the organization since it can be understood as a transfer of power to those non-family members (Alexiev et al., 2010). Therefore, the internal social capital that the company possesses or the network of external relations acquired (external social capital), can determine to a large extent the predisposition towards collaborative innovation. Hence, family SMEs in which the inclination for external knowledge prevails will encourage collaborative inter-organizational innovation, while those that value internal cooperative dynamics more will opt for intra-organizational innovation. In this sense, greater participation of new generations in the decision-making process of collaborative innovation can play a unifying role between family groups and those of non-family members of the company (Casillas, Moreno, and Barbero, 2010).

\section{Conclusions and future lines of research}

In this article, a deepening in the conceptualization of collaborative innovation strategy has been made as an increasingly common and widespread phenomenon, outlining the three main objectives pursued by this strategy: the knowledge creation and new product designs, the improved efficiency of the production process and the reduction of time-tomarket. However, the achievement of collaborative innovation in the family SMEs depends mostly on the unique characteristics of this type of organization. Thus, factors such as the management team composition -the proportion of family members or the number of 
generations involved in management- factors related to capabilities -the cognitive factors, the absorption capacity, and the innovative trajectory in terms of depth and breadth, as well as those factors referred to preferences conservation of the SEW and inter-organizational behavior-primarily mediated by the influence of the family in all cases, play a crucial role in the successful design and implementation of collaborative innovation.

The main contributions of this work refer to deepen in the solid foundations that allow in the future to delve into the academic study of collaborative innovation and the identification of differentiating characteristics of family SMEs that affect this process, which give rise to future lines of research in this field. On the one hand, a significant advance in this matter would require an empirical study of the model presented in this article, to assess the theoretical development presented here. In this sense, it would be of particular interest to consider the possible moderating effects of the size of the company and sector variables, which would allow refining the impact of the variables of this model. On the other hand, the empirical testing of the model using longitudinal data would shed light on critical decision-making whether or not to be involved in the collaborative innovation process, e.g., the time required for collaborative innovation to bring about benefits for the company.

\section{References}

Adler, P. S., and Kwon, S. W. (2002). Social capital: Prospects for a new concept. Academy of Management Review, 27(1), 17-40.

Ahuja, G., and Katila, R. (2004). Where do resources come from? The role of idiosyncratic situations. Strategic Management Journal, 25(8-9), 887-907.

Alexiev, A. S., Jansen, J. J., Van den Bosch, F. A., and Volberda, H. W. (2010). Top management team advice seeking and exploratory innovation: The moderating role of TMT heterogeneity. Journal of Management Studies, 47(7), 1343-1364.

Anderson, R. C., and Reeb, D. M. (2003). Foundingfamily ownership and firm performance: evidence from the SandP 500. The Journal of Finance, 58(3), 1301-1328.

Arzubiaga, U., Iturralde, T., Maseda, A., and Kotlar, J. (2018). Entrepreneurial orientation and firm performance in family SMEs: the moderating effects of family, women, and strategic involvement in the board of directors. International Entrepreneurship and Management Journal, 14(1), 217-244.

Arzubiaga, U. (2019). Gobernanza corporativa y orientación emprendedora de las pymes familiares: un análisis de la influencia de la implicación familiar a distintos niveles. Cuadernos de Gestión, 19(1), 119-145.

Arzubiaga, U., Kotlar, J., De Massis, A., Maseda, A., and Iturralde, T. (2018). Entrepreneurial orientation and innovation in family SMEs: unveiling the (actual) impact of the Board of Directors. Journal of Business Venturing, 33(4), 455-469.

Arzubiaga, U., Maseda, A., and Iturralde, T. (2019). Exploratory and exploitative innovation in family businesses: the moderating role of the family firm image and family involvement in top management. Review of Managerial Science, 13(1), 1-31.

Baldwin, C., and von Hippel, E. (2011). Modeling a paradigm shift: From producer innovation to user and open collaborative innovation. Organization Science, 22(6), 1399-1417.

Bourdieu, P. (1986). The forms of capital. In J. Richardson (Ed.), Handbook of Theory and Research for the Sociology of Education. New York: Greenwood, 241-258.

Brinkerink, J., and Bammens, Y. (2018). Family influence and RandD spending in Dutch manufacturing SMEs: The role of identity and socioemotional decision considerations. Journal of Product Innovation Management, 35(4), 588-608.

Casillas, J. C., Moreno, A. M., and Barbero, J. L. (2011). Entrepreneurial orientation of family firms: Family and environmental dimensions. Journal of Family Business Strategy, 2(2), 90-100.

Casillas, J. C., Moreno, A. M., and Barbero, J. L. (2010). A configurational approach of the relationship between entrepreneurial orientation and growth of family firms. Family Business Review, 23(1), 27-44.

Casprini, E., De Massis, A., Di Minin, A., Frattini, F., and Piccaluga, A. (2017). How family firms execute open innovation strategies: the Loccioni case. Journal of Knowledge Management, 21(6), 1459-1485.

Chang, Y., Hughes, M., and Hotho, S. (2011). Internal and external antecedents of SMEs' innovation ambidexterity outcomes. Management Decision, 49(10), 1658-1676.

Chirico, F. (2008). Knowledge accumulation in family firms evidence from four case studies. International Small Business Journal, 26(4), 433 462.

Chirico, F., Sirmon, D. G., Sciascia, S., and Mazzola, P. (2011). Resource orchestration in family firms: Investigating how entrepreneurial orientation, generational involvement, and participative strategy affect performance. Strategic Entrepreneurship Journal, 5(4), 307-326.

Chrisman, J. J., Chua, J. H., Pearson, A. W., and Barnett, T. (2012). Family involvement, family influence, and family-centered non-economic goals in small firms. Entrepreneurship Theory and Practice, 36(2), 267-293.

Chrisman, J. J., Chua, J. H., and Sharma, P. (2005). Trends and directions in the development of a strategic management theory of the family firm. Entrepreneurship Theory and Practice, 29(5), 555576.

Chrisman, J. J., Fang, H., Kotlar, J., and De Massis, A. (2015). A note on family influence and the adoption of discontinuous technologies in family firms. Journal of Product Innovation Management, 32(3), 384-388.

Chua, J. H., Chrisman, J. J., and De Massis, A. (2015). A closer look at socioemotional wealth: Its flows, stocks, and prospects for moving forward. Entrepreneurship Theory and Practice, 39(2), 173. 182. 
Chua, J. H., Chrisman, J. J., and Sharma, P. (1999). Defining the family business by behavior. Entrepreneurship: Theory and Practice, 23(4), 1919.

Classen, N., Van Gils, A., Bammens, Y., and Carree, M. (2012). Accessing resources from innovation partners: The search breadth of family SMEs. Journal of Small Business Management, 50(2), 191215.

Cohen, W. M., and Levinthal, D. A. (1990). Absorptive capacity: A new perspective on learning and innovation. Administrative Science Quarterly, $35,128-152$

Corsaro, D., Cantù, C., and Tunisini, A. (2012). Actors' heterogeneity in innovation networks. Industrial Marketing Management, 41, 780-789.

Cruz, C., and Nordqvist, M. (2012). Entrepreneurial orientation in family firms: A generational perspective. Small Business Economics, 38(1), 3349.

Davis, J. P., and Eisenhardt, K. M. (2011). Rotating leadership and collaborative innovation: Recombination processes in symbiotic relationships. Administrative Science Quarterly, 56(2), 159-201.

Dawson, A., and Mussolino, D. (2014). Exploring what makes family firms different: Discrete or overlapping constructs in the literature?. Journal of Family Business Strategy, 5(2), 169-183.

De Clercq, D., and Belausteguigoitia, I. (2015). Intergenerational strategy involvement and family firms' innovation pursuits: The critical roles of conflict management and social capital. Journal of Family Business Strategy, 6(3), 178-189.

De Massis, A., Chirico, F., Kotlar, J., and Naldi, L. (2013). The temporal evolution of proactiveness in family firms: The horizontal S-curve hypothesis. Family Business Review, 27(1), 35-50.

De Massis, A., Frattini, F., and Lichtenthaler, U. (2012). Research on technological innovation in family firms: Present debates and future directions. Family Business Review, 26(1), 10-31

Debicki, B. J., Kellermanns, F. W., Chrisman, J. J., Pearson, A. W., and Spencer, B. A. (2016). Development of a socioemotional wealth importance (SEWi) scale for family firm research. Journal of Family Business Strategy, 7(1), 47-57.

Duran, P., Kammerlander, N., Van Essen, M., and Zellweger, T. (2016). Doing more with less: Innovation input and output in family firms. Academy of Management Journal, 59(4), 12241264.

Faems, D., van Looy, B., and Debackere, K. (2005). Interorganizational collaboration and innovation: Toward a portfolio approach. Journal of Product Innovation Management, 22, 238-250.

Fang, H., Kotlar, J., Memili, E., Chrisman, J. J., and De Massis, A. (2018). The pursuit of international opportunities in family firms: Generational differences and the role of knowledge-based resources. Global Strategy Journal, 8(1), 136-157.

Feranita, F., Kotlar, J., and De Massis, A. (2017). Collaborative innovation in family firms: Past research, current debates, and agenda for future research. Journal of Family Business Strategy. $8(3), 137-156$.
Filip, D., Hansen, B. D., and Frølunde, T. T. (2016). Interaction enablers, drivers and barriers of collaborative innovation projects between small firms and academia. 7 Challenging traditional leadership behaviors in a distributed and ambiguous knowledge-intensive work environment, 25.

Franke, N., Schreier, M., and Kaiser, U. (2010). The "I designed it myself" effect in mass customization. Management Science, 56(1), 125140.

Fuchs, C., and Schreier, M. (2011). Customer empowerment in new product development. Journal of Product Innovation Management, 28(1), 17-32.

Galán, J. L., and Castro, I. (2004). Las relaciones interorganizativas como fuente de capital social, Universia Business Review, 2(2), 104-117.

Ganesan, S., George, M., Jap, S., Palmatier, R. W., and Barton, W. (2009). Supply chain management and retailer performance: Emerging trends, issues, and implications for research and practice. Journal of Retailing, 85, 84-94.

Gedajlovic, E., Lubaktin, M. H., and Schulze, W. S. (2004). Crossing the Threshold from Founder Management to Professional Management: A Governance Perspective. Journal of Management Studies, 41(5), 899- 912.

George, G. (2005). Slack resources and the performance of privately held firms. Academy of Management Journal, 48(4), 661-676.

Gersick, K. E., and Feliu, N. (2014). Governing the family enterprise: Practices, performance, and research. In L. Melin, M. Nordqvist, and P. Sharma (Eds.), SAGE handbook of family business. Thousand Oaks, CA: SAGE

Goel, S., and Jones III, R. J. (2016). Entrepreneurial exploration and exploitation in family business: A systematic review and future directions. Family Business Review, 29(1), 94-120.

Gómez-Mejía, L. R., Haynes, K. T., Núñez-Nickel, M., Jacobson, K. J., and Moyano-Fuentes, J. (2007). Socioemotional wealth and business risks in family-controlled firms: Evidence from Spanish olive oil mills. Administrative Science Quarterly, 52(1), 106-137.

Gomez-Mejia, L. R., Makri, M., and Kintana, M. L. (2010). Diversification decisions in family-controlled firms. Journal of Management Studies, 47(2), 223-252.

Gulati, R., Nohria, N., and Zaheer, A. (2000). Strategic networks. Strategic Management Journal, 21(3), 203-215.

Habbershon, T. G., Nordqvist, M., and Zellweger, T. (2010). entrepreneurship. Transgenerational

entrepreneurship: Exploring growth and performance in family firms across generations, 138.

Haefliger, S. (2012). Collaborative Innovation Strategy, Technology, and Social Practice (Habilitation Thesis). ETH Zurich Research Collection.

Hall, A., Melin, L., Nordqvist, M. (2001). Entrepreneurship as Radical Change in the Family Business: Exploring the Role of Cultural Patterns, Family Business Review, 14(3), 193-2008. 
Hibbert, P., and Huxham, C. (2010). The past in play: Tradition in the structures of collaboration. Organization Studies, 31(5), 525-554.

Hiebl, M. R. (2015). Family involvement and organizational ambidexterity in later-generation family businesses: A framework for further investigation. Management Decision, 53(5), 10611082.

Hitt M. A., Ireland R. D., Camp S. M., and Sexton D. L. (2001). Strategic entrepreneurship: entrepreneurial strategies for wealth creation. Strategic Management Journal, 22(6-7), 479-491.

Holmen, E., Aune, T. B., and Pedersen, A. C. (2013). Network pictures for managing key supplier relationships. Industrial Marketing Management, 42(2), 139-151.

Holt, D. T., and Daspit, J. J. (2016). Diagnosticar la disposición para la innovación en las empresas familiares. Harvard Deusto Business Review, (257), 36-50.

Instituto de Empresa Familiar de España (2016). http://www.iefamiliar.com/cifras/1 (accessed 12.03.17)

Ireland, R. D., and Webb, J. W. (2007). Strategic entrepreneurship: Creating competitive advantage through streams of innovation. Business Horizons, 50(1), 49-59.

Jensen, M. B., Johnson, B., Lorenz, E., and Lundvall, B. Å. (2007). Forms of knowledge and modes of innovation. Research Policy, 36(5), 680693.

Katila, R., and Ahuja, G. (2002). Something old, something new: A longitudinal study of search behavior and new product introduction. Academy of Management Journal, 45(6), 1183-1194.

Katz, R., and Allen, T. J. (1982). Investigating the Not Invented Here (NIH) syndrome: A look at the performance, tenure, and communication patterns of $50 \mathrm{R}$ and D Project Groups. RandD Management, 12(1), 7-20.

Kellermanns, F. W., and Eddleston, K. A. (2006). Corporate entrepreneurship in family firms: A family perspective. Entrepreneurship Theory and Practice, 30(6), 809-830.

Kellermanns, F. W., Eddleston, K. A., Barnett, T., and Pearson, A. (2008). An exploratory study of family member characteristics and involvement: Effects on entrepreneurial behavior in the family firm. Family Business Review, 21(1), 1-14.

Ketchen, D. J., Ireland, R. D., and Snow, C. C. (2007). Strategic entrepreneurship, collaborative innovation, and wealth creation. Strategic Entrepreneurship Journal, 1(3-4), 371-385.

König, A., Kammerlander, N., and Enders, A. (2013). The family innovator's dilemma: How family influence affects the adoption of discontinuous technologies by incumbent firms. Academy of Management Review, 38(3), 418-441.

Kontinen, T., and Ojala, A. (2011). Network ties in the international opportunity recognition of family SMEs. International Business Review, 20(4), 440453.

Kotlar, J., and De Massis, A. (2013). Goal setting in family firms: Goal diversity, social interactions, and collective commitment to family-centered goals. Entrepreneurship Theory and Practice, 37(6), 1263-1288.

Kotlar, J., De Massis, A., Frattini, F., and Kammerlander, N. (2019). Motivation gaps and implementation traps: The paradoxical and time-varying effects of family ownership on firm absorptive capacity. Journal of Product Innovation Management, 1-31

Kotlar, J., De Massis, A., Wright, M., and Frattini, F. (2018). Organizational goals: antecedents, formation processes and implications for firm behavior and performance. International Journal of Management Reviews, 20, S3-S18.

Kraiczy, N. D., Hack, A., and Kellermanns, F. W. (2014). New product portfolio performance in family firms. Journal of Business Research, 67(6), 1065-1073.

Le Breton-Miller, I., and Miller, D. (2006). Why do some family businesses out-compete? Governance, long-term orientations, and sustainable capability. Entrepreneurship Theory and Practice, 30(6), 731746.

Ling, Y., and Kellermanns, F. W. (2010). The effects of family firm-specific sources of TMT diversity: The moderating role of information exchange frequency. Journal of Management Studies, 47(2), 322-344.

Litz, R. A., and Kleysen, R. F. (2001). Your old men shall dream dreams, and your young men shall see visions: Toward a theory of family firm innovation with help from the Brubeck family. Family Business Review, 14(4), 335-351.

Lozano-Posso, M., and Urbano, D. (2017). Relevant Factors in the Process of Socialization, Involvement, and Belonging of Descendents in Family Businesses. Revista Innovar Journal Revista de Ciencias Administrativas y Sociales, 26(63), 6176.

Lumpkin, G. T., Brigham, K. H., and Moss, T. W. (2010). Long-term orientation: Implications for the entrepreneurial orientation and performance of family businesses. Entrepreneurship and Regional Development, 22(3-4), 241-264.

Magistretti, S., Dell'Era, C., De Massis, A., and Frattini, F. (2019). Exploring the relationship between types of family involvement and collaborative innovation in design-intensive firms: insights from two leading players in the furniture industry. Industry and Innovation, 26(10),11211151.

Mahto, R. V., Davis, P. S., Pearce, I. I., John, A., and Robinson Jr, R. B. (2010). Satisfaction with firm performance in family businesses. Entrepreneurship Theory and Practice, 34(5), 9851001.

Marcel, J. J., Barr, P. S., and Duhaime, I. M. (2010). The influence of executive cognition on competitive dynamics. Strategic Management Journal, 32, 115-138.

Mazzi, C. (2011). Family business and financial performance: Current state of knowledge and future research challenges. Journal of Family Business Strategy, 2(3), 166-181.

Menon, T. and Pfeffer, J. (2003). 'Valuing internal vs. external knowledge: explaining the preference for outsiders.' Management Science, 49, 497-513.

Miles, R. E., Miles, G., and Snow, C. C. (2005). Collaborative entrepreneurship: How communities of networked firms use continuous innovation to create economic wealth. Stanford University Press.

Min, S., Roath, A. S., Daugherty, P. J., Genchev, S. E., Chen, H., Arndt, A. D., and Richey, R. G. (2005). Supply chain collaboration: What's 
happening? International Journal of Logistics Management, 16, 237-256.

Minichilli, A., Corbetta, G., and MacMillan, I. C. (2010). Top management teams in familycontrolled companies: 'familiness,' 'faultlines,' and their impact on financial performance. Journal of Management Studies, 47(2), 205-222.

Muñoz-Bullón, F., Sanchez-Bueno, M. J., and De Massis, A. (2019). Combining Internal and External R\&D: The Effects on Innovation Performance in Family and Nonfamily Firms. Entrepreneurship Theory and Practice, 1042258719879674.

Nahapiet, J., and Ghoshal, S. (1998). Social capital, intellectual capital, and the organizational advantage. Academy of Management Review, 23(2), 242-266.

Naldi, L., Nordqvist, M., Sjöberg, K., and Wiklund, J. (2007). Entrepreneurial orientation, risk-taking, and performance in family firms. Family Business Review, 20(1), 33-47.

Negocios en Navarra (2016). Available online: http://www.negociosennavarra.com/mercadonaimpulsa-la-innovacion-colaborativa-proveedores/

Nordqvist, M., Sharma, P., and Chirico, F. (2014). Family firm heterogeneity and governance: A configuration approach. Journal of Small Business Management, 52(2), 192-209.

Öberg, C. (2016). What creates a collaboration-level identity? Journal of Business Research, 69(9), 3220-3230.

Paunov, C. (2012). The global crisis and firms' investments in innovation. Research Policy, 41(1), 24-35.

Pattikawa, L. H., Verwaal, E., and Commandeur, H. R. (2006). Understanding new product project performance. European Journal of Marketing, 40(11/12), 1178-1193.

Pearson, A.W., Carr, J. C., and Shaw, J. C. (2008). Toward a theory of familiness: a social capital perspective. Entrepreneurship Theory and Practice, 32(6), 949-969.

Reagans, R., Zuckerman, E., and McEvily, B. (2004). How to make the team: Social networks vs. demography as criteria for designing effective teams. Administrative Science Quarterly, 49(1), 101-133.

Rodan, S., and Galunic, C. (2004). More than network structure: How knowledge heterogeneity influences managerial performance and innovativeness. Strategic Management Journal, 25(6), 541-562.

Rondi, E., De Massis, A., and Kotlar, J. (forthcoming). Unlocking innovation potential: A typology of family business innovation postures and the critical role of the family system. Journal of Family Business Strategy. 1-13.

Roxas, S.A., Piroli, G., and Sorrentino, M. (2011). Efficiency and evaluation analysis of a network of technology transfer brokers, Technology Analysis and Strategic Management, 23(1), 7-24.

Roy, S., and Sivakumar, K. (2010). Innovation generation in upstream and downstream business relationships. Journal of Business Research, 63(12), 1356-1363.

Rumball, D. (2007). Case studies of collaborative innovation in Canadian small firms. Small Business Policy Branch, Industry Canada.
Sánchez-Famoso, V., Iturralde, T., and Maseda, A. (2015). The Influence of Family and Non-Family Social Capital on Firm Innovation: Exploring the Role of Family Ownership, European Journal of International Management, 9(2), 1-15.

Sánchez-Famoso, V., Maseda, A., and Iturralde, T. (2017). Family involvement in top management team: impact on relationships between internal social capital and innovation, Journal of Management and Organization, 23(1), 136-162.

Sciascia, S., Mazzola, P., and Chirico, F. (2013). Generational involvement in the top management team of family firms: Exploring nonlinear effects on entrepreneurial orientation. Entrepreneurship Theory and Practice, 37(1), 69-85.

Seibert, S. E., Kraimer, M. L., and Liden, R. C. (2001). A social capital theory of career success. Academy of Management Journal, 44(2), 219-237.

Skippari, M., Laukkanen, M., and Salo, J. (2017). Cognitive barriers to collaborative innovation generation in supply chain relationships. Industrial Marketing Management, 62, 108-117.

Souder, D., Zaheer, A., Sapienza, H., and Ranucci, R. (2016). How family influence, socioemotional wealth, and competitive conditions shape new technology adoption. Strategic Management Journal, 38(9), 1774-1790.

Spithoven, A., Vanhaverbeke, W., and Roijakkers, N. (2013). Open innovation practices in SMEs and large enterprises. Small Business Economics, 41(3), 537-562.

Steiger, T., Duller, C., and Hiebl, M. R. (2015). No consensus in sight: an analysis of ten years of family business definitions in empirical research studies. Journal of Enterprising Culture, 23(1), 2562.

Street, C. T., and Cameron, A. F. (2007). External relationships and the small business: A review of small business alliance and network research. Journal of Small Business Management, 45(2), 239 . 266.

Swink, M. (2006). Building collaborative innovation capability. Research-Technology Management, 49, 37-47

Talke, K., Salomo, S., and Rost, K. (2010). How top management team diversity affects innovativeness and performance via the strategic choice to focus on innovation fields. Research Policy, 39(7), 907918.

Tsai, S. P. (2009). Modeling strategic management for cause-related marketing. Marketing intelligence and planning, 27(5), 649-665.

Un, C. A., Cuervo-Cazurra, A., and Asakawa, K. (2010). R\&D collaborations and product innovation. Journal of Product Innovation Management, 27(5), 673-689.

Veider, V., and Matzler, K. (2015). The ability and willingness of family-controlled firms to arrive at organizational ambidexterity. Journal of Family Business Strategy, 7(2), 105-116.

Venkatesh, S., and Yadav, M. S. (2011). Innovations in retailing. Journal of Retailing, 87S(1), S1-S2.

Vieira, E. S. (2014). Corporate risk in family businesses under economic crisis. Revista Innovar Journal Revista de Ciencias Administrativas y Sociales, 24(53), 61-73. 
Von Hippel, E., and Krogh, G. V. (2003). Open source software and the "private-collective" innovation model: Issues for organization science. Organization Science, 14(2), 209-223.

Zahra, S. A. (2005). Entrepreneurial risk-taking in family firms. Family Business Review, 18(1), 23-40.

Zahra, S. A., and George, G. (2002). Absorptive capacity: A review, reconceptualization, and extension. Academy of Management Review, 27(2), 185-203.

Zellweger, T. (2007). Time horizon, costs of equity capital, and generic investment strategies of firms. Family Business Review, 20(1), 1-15.

Zellweger, T. M., Eddleston, K. A., and Kellermanns, F. W. (2010). Exploring the concept of familiness: Introducing family firm identity. Journal of Family Business Strategy, 1(1), 54-63.

Zúñiga-Vicente, J. Á., Alonso-Borrego, C., Forcadell, F. J., and Galán, J. I. (2014). Assessing the effect of public subsidies on firm RandD investment: a survey. Journal of Economic Surveys, 28(1), 36-67. 